Article

\title{
Experimental Governance and Urban Planning Futures: Five Strategic Functions for Municipalities in Local Innovation
}

\author{
Erica Eneqvist ${ }^{1,2, *}$ and Andrew Karvonen ${ }^{1}$ \\ ${ }^{1}$ Department of Urban Planning and Environment, KTH Royal Institute of Technology, 10044 Stockholm, Sweden; \\ E-Mails: ericaen@kth.se (E.E.), apkar@kth.se (A.K.) \\ 2 Division of Built Environment, RISE Research Institutes of Sweden, 11486 Stockholm, Sweden \\ * Corresponding author
}

Submitted: 25 June 2020 | Accepted: 3 November 2020 | Published: 26 March 2021

\begin{abstract}
Experimental governance is increasingly being implemented in cities around the world through laboratories, testbeds, platforms, and innovation districts to address a wide range of complex sustainability challenges. Experiments often involve public-private partnerships and triple helix collaborations with the municipality as a key stakeholder. This stretches the responsibilities of local authorities beyond conventional practices of policymaking and regulation to engage in more applied, collaborative, and recursive forms of planning. In this article, we examine how local authorities are involved in experimental governance and how this is influencing their approach to urban development. We are specifically interested in the multiple strategic functions that municipalities play in experimental governance and the broader implications to existing urban planning practices and norms. We begin the article by developing an analytic framework of the most common strategic functions of municipalities in experimental governance and then apply this framework to Stockholm, a city that has embraced experimental governance as a means to realise its sustainability ambitions. Our findings reveal how the strategic functions of visioning, facilitating, supporting, amplifying, and guarding are producing new opportunities and challenges to urban planning practices in twenty-first century cities.
\end{abstract}

\section{Keywords}

collaboration; experimental governance; experimentation; municipalities; urban planning

Issue

This article is part of the issue "Urban Planning by Experiment" edited by Christian Scholl (Maastricht University, The Netherlands) and Joop de Kraker (Maastricht University, The Netherlands).

(C) 2021 by the authors; licensee Cogitatio (Lisbon, Portugal). This article is licensed under a Creative Commons Attribution 4.0 International License (CC BY).

\section{Introduction}

Cities around the world are embracing experiments as a means to achieve their sustainability goals. Various stakeholders engage in experiments to demonstrate that improved urban futures are possible through laboratories, testbeds, platforms, and innovation districts (Bulkeley \& Castán Broto, 2013; Bulkeley et al., 2019; Evans, Karvonen, \& Raven, 2016; Kivimaa, Hildén, Huitema, Jordan, \& Newig, 2017; Scholl \& Kemp, 2016; Sengers, Wieczorek, \& Raven, 2019). Cities are framed as both the loci of societal challenges and critical locales to trial solutions, and have been described as "seedbeds for local innovation niches" (Wolfram \& Frantzeskaki, 2016, p. 144). Experiments inform new modes of experimental governance to address complex sustainability issues at the local level (Bulkeley \& Castán Broto, 2013; Evans et al., 2016) and provide opportunities to "try out pathways to these desirable futures" (Meadowcroft, 2009, p. 325). Urban experiments vary in purpose, scope, and size but tend to share several common characteristics that combine sustainability, innovation, co-creation, and learning with a place-based focus (Bulkeley et al., 2016; Evans \& Karvonen, 2014). The aim of experiments is to "design, test and learn from innovation in real time in order to respond to particular societal, economic and 
environmental issues in a given urban place" (Bulkeley et al., 2016, p. 13).

Experiments frequently involve collaborations between local governments, private companies, academia, and civil society to satisfy external funding requirements and to address the complexity of contemporary urban challenges (van der Heijden, 2018). Municipalities are key actors in these partnerships and often lead the experimental actions in cities (Bulkeley \& Castán Broto, 2013; van der Heijden, 2015; Warbroek \& Hoppe, 2017). This is logical as local governments have multiple resources at their disposal as well as longstanding experience and state-sponsored authority to govern urban development processes. Recent research has highlighted the various ways that local authorities contribute to urban experiments (Bulkeley \& Kern, 2006; Kronsell \& Mukhtar-Landgren, 2018; Mukhtar-Landgren, Kronsell, Voytenko Palgan, \& von Wirth, 2019). However, the broader strategic functions of the municipality beyond individual experiments requires further scrutiny to understand how experimental governance is informing urban planning practices. Experimental governance includes both vertical approaches (i.e., top-down and bottom-up) and horizontal strategies to navigate particular social, institutional, and physical conditions (Laakso, Berg, \& Annala, 2017). This involves governing through experimental practices rather than experimenting with the governance system itself.

In this article, we draw upon literature from urban studies, policy analysis, and political science to develop an analytic framework of strategic functions performed by local authorities in experimental governance. We then apply this framework to Stockholm - a municipality that has embraced experimental governance to achieve its sustainability ambitions - to understand how these functions influence urban planning. The focus is not on isolated experiments but rather on how these activities collectively influence practices of governance and urban planning (Frantzeskaki, Hölscher, Wittmayer, Avelino, \& Bach, 2018; Karvonen, 2018). In other words, we are looking beyond individual interventions to examine how municipalities contribute to broader processes of local innovation through experimental governance. The study addresses the following research question: What strategic functions do municipalities perform in experimental governance? The findings highlight the multiple ways that local authorities contribute to experimental governance and how this is influencing existing practices of urban planning.

\section{Experimental Governance and the Strategic Functions of Municipalities}

Municipalities are traditionally structured as hierarchical, vertical, and sectorised organisations with a strong silo orientation that uses formal rules to control and stabilise collective interests (Agger \& Sørensen, 2018; Lundquist, 1998; March \& Olsen, 1989). They act to develop and change cities through established mechanisms of governance (e.g., master planning, policy making, regulations) while working carefully to minimise risks and avoid making mistakes (Torfing, 2012). In contrast, experimental governance recasts the role of local governments from a vertical, hierarchical structure with clearly defined responsibilities to a more horizontal, collaborative structure with fluid, distributed responsibilities (Pierre, 2011). Collaboration is a cornerstone of experimental governance where different actors contribute in multiple ways to develop synergistic solutions that cannot be achieved by a single actor (Nyström, Leminen, Westerlund, \& Kortelainen, 2014). As Berkhout et al. (2010, p. 262) note, "experiments typically bring together new networks of actors with knowledge, capabilities and resources, cooperating in a process of learning."

The collaborative character of experimental governance has significant influence on the work of public authorities. Previous studies have defined the actions of local governments in individual experiments. Notably, Kronsell and Mukhtar-Landgren (2018) studied urban living labs and found that municipalities play multiple roles that vary over time and between municipal departments within the same lab. Specifically, they found that municipalities operate as enablers, partners, and promotors. Meanwhile, Bulkeley and Kern (2006) focused on climate experiments and the ability of local governments to influence experimental outcomes. They found that municipalities govern by authority, provisioning, and enabling, as well as through self-governance. This study builds upon the results of these previous studies to describe the broader strategic functions of municipalities in experimental governance. These strategic functions are directly related to the contributions of public authorities to urban planning processes (Pierre \& Sundström, 2009; Warbroek \& Hoppe, 2017). We developed an analytic framework that includes four functions inspired by the previous research and then complemented these with a fifth function to address the local government as the guardian of the public good (Lundquist, 1998). It is important to note that local governments are seldom coherent actors with clear visions and targets. Instead, they are comprised of "different departments, individuals, and political interests that need to cooperate, and ignore, compete, and struggle with each other" (Hölscher, Avelino, \& Wittmayer, 2018, p. 147). Thus, the strategic functions that municipalities play in all processes are rarely coherent and can at times be contradictory.

In the following paragraphs, we summarise five strategic functions performed by local authorities in experimental governance: visioning, facilitating, supporting, amplifying, and guarding. These functions are derived from contemporary discourses on experimental governance, collaborative governance, and urban innovation. We selected these functions because they describe many ways that municipalities contribute to the various phrases of experimentation as well as urban development more generally. The purpose of the 
framework is to characterise the broader implications of experimental governance beyond the actions of a single experiment. The resulting categories can then be used to analyse how local governments engage in and contribute to experimental governance, from initial visions and implementation of experiments to the application of the experimental findings and the steering of urban development processes. It is important to note that the framework is designed as a heuristic tool to analyse the influence of municipalities on experimental governance. The identified functions are not intended to be comprehensive or mutually exclusive but instead can be combined and extended in various ways.

\subsection{Visioning}

A primary function for municipalities is to frame values, norms, and perceptions (Kickert \& Koppenjan, 1997). Visionary planning is a long-standing practice for local authorities to promote a clear trajectory for a desired collective future (Pierre \& Sundström, 2009). Municipalities use visions to position their contextspecific issues within a policy area, to formulate problems, to assemble different departments around a specific policy, to communicate the municipality's position to other organisations, and to facilitate collaboration and engagement (Bulkeley \& Kern, 2006; Mey, Diesendorf, \& MacGill, 2016; Mukhtar-Landgren \& Smith, 2019). The vision is a tool for change within the local government (Brorström, 2015) with respect to "shaping the playing field" (Warbroek \& Hoppe, 2017, p. 2). Other stakeholders can inform shared visions, but municipalities are frequently the drivers of visioning processes to steer local stakeholders towards long-term collective urban planning goals.

\subsection{Facilitating}

Beyond the promotion of long-term shared visions, municipalities facilitate engagement between urban stakeholders while maintaining and nurturing experiments (Hölscher et al., 2018; Mey et al., 2016; Pierre, 2011). It is commonplace for local governments to lead experimental activities and to facilitate the interactions among the stakeholders (Agranoff \& McGuire, 2001; Kronsell \& Mukhtar-Landgren, 2018) by building trust, developing contacts, identifying resources, and maintaining a common agenda (Kickert \& Koppenjan, 1997). The local government also serves as a meta-governor to link experimental actions with conventional governance tools and to ensure the coherence of municipal actions (Jessop, 1997) by enabling and coordinating the actions of stakeholders (Bulkeley \& Kern, 2006).

\subsection{Supporting}

Closely related but distinct from facilitating is the function of supporting. This is a more passive function that involves provisioning and assisting rather than leading (Bulkeley \& Kern, 2006). The municipality provides services, resources, and infrastructure to assist with experiments as well as permits and other types of administrative support where they have authority and influence (Mey et al., 2016; Warbroek \& Hoppe, 2017). In some instances, municipalities provide buildings, open spaces, and infrastructure networks to serve as physical venues where experiments can be conducted (Kronsell \& Mukhtar-Landgren, 2018; Mey et al., 2016). The supporting function is attractive for municipalities who lack the resources or expertise to lead on experiments but still want to contribute. However, the passive character of supporting results in less control over the experimental agenda and a reduced ability for the local authority to align the experiments with shared long-term visions.

\subsection{Amplifying}

A key expectation of urban experiments is to upscale and replicate results (Kern, 2019; Lam et al., 2020). Municipalities are often responsible for applying experimental results to new policies, guidelines, and regulations, and can also use experimental results to reorganise their internal operations by establishing new protocols and procurement requirements (Mey et al., 2016). Here, the local government serves as a role model for other organisations (referred to as "self-governing" in Bulkeley \& Kern, 2006) while also influencing market conditions for the adoption of new technologies (i.e., electric vehicles, photovoltaics). Finally, municipalities promote their experimental findings to higher levels of government (regional, national, and international) and to other cities through information sharing and knowledge exchange (Mey et al., 2016). Here, amplifying activities involve the circulation of knowledge among global networks and feed into competitive rankings and awards that are used by cities for reputation building and external promotion (de Jong, Joss, Schraven, Zhan, \& Weijnen, 2015; Vanolo, 2017).

\subsection{Guarding}

A critical function of public authorities in urban experiments is to protect public values (Kronsell \& MukhtarLandgren, 2020; Raven et al., 2019). The collaborative approach to experimental governance has a tendency to blur power relations and decision-making responsibilities, with important implications to democratic accountability (Karvonen, 2018; Pierre, 2011). Experiments disrupt traditional planning approaches (Agger \& Sørensen, 2018) and these changes reinforce the mandate of the local government as "the guarantor of public values" (Bryson, Crosby, \& Bloomberg, 2014, p. 445). This includes an obligation to safeguard public welfare while "balancing short run interests against a long-run, 'greater good' perspective" (Nalbandian, 1999, p. 194). The municipality is charged with ensuring that 
experiments address the most relevant issues (Scharpf, 1999) and align with the existing set of local policies. Guarding involves protecting and promoting collective values such as democracy, legality, impartiality, transparency, and rule of law, all of which are unique to the public sector (Lundquist, 1998). As such, guarding cannot be easily performed by other actors.

The five strategic functions of municipalities in experimental governance are summarised in Table 1. The functions embody different types of expertise, aims, and target audiences. There are multiple synergies and tensions between these functions and they are shared across different individuals and departments through the various experimentation phases. A municipality could perform all these functions simultaneously and have a significant influence on experimental governance or only perform a single function and allow other actors to drive the experimental agenda.

\section{Methodology}

To apply the framework of strategic functions as described above, we conducted a deductive case study of experimental governance in Stockholm. Swedish municipalities have an explicit and strong mandate for selfgovernance with significant responsibilities for urban planning that include a planning monopoly and extensive land ownership (Montin \& Granberg, 2007; Rutherford, 2008). Stockholm is the largest city in Sweden and actively participates in global networks such as C40 and ICLEI to realise their sustainability ambitions. More importantly, the municipality promotes collaborative experiments in their strategies and engages with universities as well as a range of local, national, and international companies to develop high-profile demonstration sites, laboratories, and testbeds throughout the city (City of Stockholm, 2020a). The Stockholm municipal government can be understood as a typical case study (Flyvbjerg, 2006) of how local governments around the world are engaging in experimental governance to realise their environmental, economic, and social goals. While the experiments are specific to this particular context, the general strategy and ethos of experimental governance is similar in many cities.

For this study, we gathered empirical data through a desk-based analysis of publicly accessible documents and websites and a review of all externally funded projects in Stockholm from 2010 to 2018 to identify those that involved experiments. We then used this secondary data to identify and recruit relevant respondents with knowledge about the municipal functions in experimental governance. We conducted semi-structured interviews with 12 municipal officials (Table 2 ) between June and December 2019, including 10 in-person and two video conference interviews that lasted from 60 to 90 minutes. We audio recorded and transcribed the interviews and then analysed the collected data by applying the five municipal functions through coding via qualitative data analysis software (Nvivo). All direct quotations are translated from Swedish.

\section{Findings and Analysis}

In the following sub-sections, we provide a brief overview of experimental governance in Stockholm and then present findings of the five strategic functions, and reflect on how they influence urban planning practices in the city.

\subsection{Experimental Governance in Stockholm}

The City of Stockholm has a long-standing commitment to sustainable urban development as well as a tradition of partnerships with industry and academia, and more recently, an ambition to be the smartest city in the world (City of Stockholm, n.d.-b). Stockholm's Comprehensive Plan states that the municipality "actively encourages companies and institutions to use the city's land and operations as a testbed for new innovations" (City of Stockholm, 2018, p. 58f). A prominent example of a municipal experiment is the high-profile environmental showcase, Hammarby

Table 1. Five strategic functions of municipalities in experimental governance.

\begin{tabular}{|c|c|c|c|c|c|}
\hline & Visioning & Facilitating & Supporting & Amplifying & Guarding \\
\hline Expertise & $\begin{array}{l}\text { Collective } \\
\text { leadership }\end{array}$ & $\begin{array}{l}\text { Networking and } \\
\text { driving }\end{array}$ & $\begin{array}{l}\text { Administration } \\
\text { and assistance }\end{array}$ & $\begin{array}{l}\text { Knowledge } \\
\text { translation and } \\
\text { application }\end{array}$ & $\begin{array}{l}\text { Democracy and } \\
\text { representation }\end{array}$ \\
\hline Aims & $\begin{array}{l}\text { Define and } \\
\text { achieve shared } \\
\text { goals }\end{array}$ & $\begin{array}{l}\text { Initiate and steer } \\
\text { experiments }\end{array}$ & $\begin{array}{l}\text { Support } \\
\text { experiments }\end{array}$ & $\begin{array}{l}\text { Apply and upscale } \\
\text { experimental } \\
\text { results }\end{array}$ & $\begin{array}{l}\text { Protect democratic } \\
\text { values }\end{array}$ \\
\hline Target audience & $\begin{array}{l}\text { Experimental } \\
\text { partners and } \\
\text { local constituents }\end{array}$ & $\begin{array}{l}\text { Experimental } \\
\text { partners }\end{array}$ & $\begin{array}{l}\text { Experimental } \\
\text { partners }\end{array}$ & $\begin{array}{l}\text { Municipalities, } \\
\text { national } \\
\text { government, } \\
\text { global networks }\end{array}$ & Local constituents \\
\hline
\end{tabular}


Table 2. List of Stockholm respondents.

\begin{tabular}{llll}
\hline R1 & Innovation strategist & R7 & Mobility specialist \\
R2 & Innovation strategist & R8 & Mobility specialist \\
R3 & Innovation strategist & R9 & Sustainable planning specialist \\
R4 & Environmental strategist & R10 & Platform developer \\
R5 & Innovation strategist & R11 & ICT specialist \\
R6 & Smart city specialist & R12 & Smart city developer \\
\hline
\end{tabular}

Sjöstad, an eco-district that achieved global acclaim beginning in the mid-1990s (Iveroth, Vernay, Mulder, \& Brandt, 2013; Rutherford, 2020). More recent examples of experiments, testbeds, and platforms include the European Smart Cities Lighthouse demonstration project GrowSmarter (GrowSmarter, n.d.), the Royal Seaport mixed-use Brownfield re-development (City of Stockholm, 2020b), and the Urban ICT Arena, a public-private digital testbed (City of Stockholm, n.d.-a). Together, these projects and programmes illustrate the City of Stockholm's embrace of experimental governance to realise its long-term goals.

The City of Stockholm's approach to experimental governance is exemplified by different modes of collaboration, many of which involve long-term collaborations with local universities and international businesses (Solesvik, 2017). These collaborations were initially established to promote the city and develop the regional economic base. More recent partnerships have broadened the agenda to focus on solving common challenges together under the banner of sustainable urban development. Several of the respondents emphasised this more strategic collaboration focus. An innovation strategist (R1) noted: "We have had collaboration before, but mostly from a growth and business perspective, in order to establish the industry here. It was not about solving our challenges, but now...it's a completely different way of working, more strategic." Another innovation strategist (R3) claimed that "we need to use it [experimentation] strategically to reach a goal." This points towards an expansion of collaboration activities beyond entrepreneurialism to focus on collective problem-solving (Kivimaa et al., 2017).

The respondents had different opinions about experimental governance as an alternative to traditional planning processes (Agger \& Sørensen, 2018). One respondent (R9) recognised the utility of experiments, stating that "we need to experiment. We don't always have the excellent competence, but we can offer the city as an arena for research." Another respondent (R7) added that experimental governance is promoted by the municipal leadership: "It is a message that is conveyed from the top management. We want to see the city as a testbed and we should dare to test new solutions." This reflects a specific framing of the city as a site of innovation as promoted by municipal leaders. Other respondents were more sceptical of experimental governance due to the various risks involved. An environmental strategist (R4) highlighted the risks, arguing that "you can't experiment within the built environment. And you can't experiment with tax money either." Thus, experimental governance is contested among those who initiate and engage in innovation activities.

\subsection{Visioning}

The visionary function is used to develop a roadmap to achieve desired futures and to strategise on the creation of spaces for action (Brorström, 2015; Gaffikin \& Sterrett, 2006). The City of Stockholm's visions are summarised in documents such as Vision 2040 and the Comprehensive Plan as well as programmes related to environmental protection and digitalisation, among many others (City of Stockholm, 2015, 2018, 2020c). The visionary function allows the municipality to set the agenda for experimental governance while exerting its authority to protect its long-standing position as the lead actor in planning processes (Bulkeley \& Kern, 2006). The vision documents provide guidance when considering which particular experiments to support. As an innovation strategist (R1) succinctly noted, "the policy documents steer our actions." This implies that the traditional planning approach continues to be at the core of experimental governance with an emphasis on realising longterm collective goals. The same respondent went on to note that public actors have a special function among other partners:

There is a need for public representatives, at both the local and regional level, to take the lead in the discussions about challenges. We need to decide which issues are prioritised. We should have that role, not the companies. By doing so, we create clear conditions for the companies to act upon.

This perspective positions the municipality as the leader of experimental governance to define the direction of specific interventions as well as the broader trajectory of innovation in the city. Another respondent (R2) worried that the visions for experimental governance are actually set by other actors and this reduces the influence of the local government: "Unfortunately, I believe that the initiatives to a very, very large extent come from outside actors." In other words, the inclusion of multiple actors results in less control of urban development processes by the public authority (Pierre, 2011). This has the potential to rearrange decision making capacities among urban stakeholders with fundamental implications to 
urban planning practices. Several of the respondents emphasised that visioning is not so much about establishing long-term goals (as is commonplace in traditional urban planning) but is rather about problem identification and solution generation. "We need to push issues more clearly, steer towards our long-term challenges and be the problem owners from beginning to end. We cannot just open up a place for others to play, we must take it back to us" (R4). In other words, they recognised the tensions between long-term, collective visions and shortterm goals that can be achieved through particular experimental activities.

At the same time, several respondents were frustrated with existing goals because they tend to be too broad and lack prioritisation. This illustrates a disconnect between experimental governance and traditional urban planning. One innovation strategist (R2) argued that the goals "include everything, we can do everything" while another innovation strategist (R3) added that "the goals don't give direction." The lack of prioritisation is further compounded by the large number of goals that make it difficult to orient and focus. For example, a respondent (R2) noted, "When I worked in elderly care, we had 130 goals to achieve in a year. How do you prioritise them? It becomes 'goal obfuscation."' Another respondent (R1) stated that, "We don't even know by ourselves what is the most important thing to do, so it's exciting when companies say that they know." In this sense, experimental governance provides an opportunity to cut through the multitude of existing goals and 'cherry-pick' those that can be readily addressed through experimentation. This selection process prioritises some goals over others while opening up a space for other actors to set the experimental agenda (Karvonen, Evans, \& van Heur, 2014). Thus, the visionary function allows the municipality to reinforce its position as the driver of urban development while the experimental activities tend to focus in on specific interventions that favour a select number of long-term planning goals while ignoring others.

\subsection{Facilitating}

Beyond visioning, the respondents provided multiple insights on how the municipality facilitates experimental governance. Facilitating involves a combination of leadership and intermediation to steer partnerships and to ensure that various stakeholders are working towards shared aims and objectives. The facilitator is the catalyst of experimental governance and actively works to connect the stakeholders and keep them on track (Hölscher et al., 2018; Kronsell \& Mukhtar-Landgren, 2018). The local government is a logical stakeholder to take on the facilitative function, but evidence from Stockholm highlights multiple challenges related to existing organisational structures and a general lack of competence in facilitation.

The strongest form of facilitation extends the visionary function of municipalities by positioning them as the leaders of experimental activities. They not only set the agenda for experiments but also ensure that the relevant actors are continuously engaged (Kronsell \& Mukhtar-Landgren, 2018, describe this as a promotor role). As one respondent (R4) noted, "We have to come in and take command here, to control things." This reinforces the municipality as the most influential actor of urban development processes while supporting the work of other actors in achieving shared goals. An innovation strategist (R5) provides a concrete example of this, stating that "we have an ambition to apply for external funding in order to help the construction companies, we want to help pave the road to get them started."

In addition to leading, facilitating is also about having an overview of and an ability to link the relevant actors to one another. A mobility specialist (R7) suggested that the municipality functions as an intermediary to facilitate connections between stakeholders: "We are something of a neutral platform. It is logical that we as a municipality connect actors and push the different sectors." Local governments manage the internal connections between local actors and the external connections to other municipalities with similar challenges and aims (R4). Some of the respondents see themselves as facilitators on an individual level, referring to themselves as orchestrators (R10), process leaders and networkers (R7), and collaborators (R4). An innovation strategist (R5) summarised this by stating that "there is a need to have people employed by the city that work for better collaboration between business, academia, and the city." Thus, facilitating involves both leading agendas and connecting up stakeholders in strategic ways.

\subsection{Supporting}

In addition to actively facilitating experimental governance, the municipality provides passive support through the provision of services, resources, and infrastructure (Kronsell \& Mukhtar-Landgren, 2018). The respondents largely take this work for granted, noting that there is nothing special or controversial about providing buildings, roads, permits, and the built environment for experimental activities. "If we want an environment around the City of Stockholm that is open to research, then we have to deliver, we have to open up," noted an innovation strategist (R3). A mobility specialist (R7) continued: "We have given these actors a different type of dispensation so that they can perform tests."

The respondents largely agreed that the duty of the municipality is to support actions that have the potential to improve the city as a whole as long as it contributes to their overarching visions and goals. A concrete example of this is the designation of specific parts of the city as testbeds. One respondent (R9) reflected on the Urban ICT Arena, noting: "We have stated that the urban development in Kista will be used as a testbed to develop and test new ideas." Here, the municipality provides the foundation upon which experimental actors can conduct 
their activities but does not play an active part in day-today activities. Instead, they leave these activities to other stakeholders and only provide support when needed.

The municipality also contributes to experimental governance by writing letters of support for researchers who are submitting external funding applications. Letters of support demonstrate that the proposed research project has the explicit endorsement of the public authority. An innovation strategist (R1) was not pleased with this supportive activity, stating that: "They want us to join, but we should not play the legitimising role just for others to get funding." The respondent continued by expressing a similar dissatisfaction with merely supporting experiments, arguing that "we cannot just make a street available. If we are about to spend our time and use our city as a testbed, then we also need to benefit from it. It is about prioritising some projects and not others." This highlights the inherent tensions in the supporting function as they relate to the responsibility and influence of the local government (Karvonen et al., 2014). The respondents see the supporter function as a necessary but insufficient way for the municipality to participate in experimental governance. They interpret supportive work as simultaneously unproblematic and dissatisfying, suggesting the need for more deliberative reflection when deciding if a proposed experiment should be supported and if so, what type of support should be provided by the municipality and through which departments and individuals.

\subsection{Amplifying}

The amplifying function focuses on upscaling and transferring the results of experiments through replication and diffusion (Kern, 2019; Lam et al., 2020). The respondents recognised the ambitions to learn from experiments and apply them to the city more broadly but also stressed that these processes tend to be difficult and do not happen automatically. Some respondents were optimistic about the implementation of successful experimental results through existing budget allocation procedures. "We will come up with the ideas and then test and validate them. If they are good, then we decide in the budget process how it should be prioritised throughout the city" (R1). Another respondent (R9) adopted a more critical perspective on this process, noting that "we sometimes believe so much in the budget document, but not everything can be implemented through it, especially not those things that require organisational change."

Several of the respondents highlighted significant organisational challenges to internal upscaling and implementation. An innovation strategist (R1) concluded that "we are bad at it. We need to be much better. But we can't really. We don't have the skills for upscaling and spreading" (R1). Other respondents had similar critiques: "It happens, but it is arbitrary and person dependent" (R7); "It is an overall problem within the city, to internalise the learning" (R5); "We don't have an internal organisation for our knowledge generation" (R3); "And it is a matter of power, which becomes tricky when it becomes an individual responsibility rather than an organisational one" (R4). This highlights multiple gaps between generating experimental results and applying them to broader urban planning processes and structures.

A key challenge of upscaling involves the translation of results from time-limited experiments into permanent organisational structures (Hodgson, Fred, Bailey, \& Hall, 2019). An innovation strategist (R5) argued that "it is not only about upscaling; it is about implementation, to avoid another project result on the shelf." This perspective recognises that experiments are not an end in themselves but rather serve to inform broader urban development processes. Here, there is a clear disconnect between experiments and traditional modes of urban planning and development. Experiments are often initiated by individuals without an explicit strategy to embed the findings into the overall organisation, resulting in a tenuous connection to other municipal activities. To address this, an innovation strategist (R2) suggested that:

When starting a project, a larger round-table conversation would be needed in the organisation. Does this meet our needs and goals? Do we have the opportunity? Then we would have a structure for this innovation idea or lab to grow afterwards.

In other words, there is a need for more deliberate and reflective processes of learning in experimental governance to link short-term experimental interventions to long-term urban planning processes (McFarlane, 2011; Wolfram, van der Heijden, Juhola, \& Patterson, 2019).

The large and heterogeneous character of local governments also hampers the amplification of experimental results. An environmental strategist (R4) noted: "It is the wrong department that has driven the project. The result is not customisable to the rest of the organisation." Thus, the appropriate municipal actors need to be included from the start in the design and execution of the experiments as well as in the application of the experimental results. Another problem with the limitation and scale of experiments is that similar solutions are often appropriate for different departments, but the departments fail to recognise that they have related problems. As a smart city strategist (R12) explained:

The needs are very similar, but [municipal departments] don't know each other, or have a city overview. This results in the creation of individual solutions.... which often end up being too expensive for a single department. When others discover the positive result, it is too late, it is not scalable.

This reflects back on the shared visions and a lack of alignment across municipal departments (Hölscher et al., 2018). 
The empirical findings from Stockholm reveal that the amplifying function was of critical importance to the municipality, but that there are numerous organisational challenges regarding learning, scaling, and implementation. Previous research has shown the need to connect experiments to on-going processes and institutional settings in order to implement results effectively (Bos \& Brown, 2012). The overall sense of frustration regarding the amplifying function highlights the challenges that need to be addressed before the local government can use their multiple levers of governance (Bulkeley \& Kern, 2006) to benefit from the outcomes of experiments. Specifically, amplifying requires commitment and planning from the early stages of experimentation rather than being considered as an afterthought.

\subsection{Guarding}

The guarding function, where the local government protects minority interests and public values, is relevant in all phases of experimentation, from problem formulation to implementation and generation of results. The function serves as the moral backbone of experimental governance to ensure that public values are maintained when engaging in innovation activities. The respondents recognised the unique responsibility of the public actor to promote democracy and transparency in experimental partnerships while also forwarding citizen perspectives and adopting a holistic overview (Bryson et al., 2014). Experiments are often about testing something new and by design; this challenges the existing modus operandi (Agger \& Sørensen, 2018). A platform developer (R10) succinctly stated: "How can we open up to enable all these new activities without compromising integrity, democracy, transparency and publicity? This is where the municipality is central." The same respondent added: "The municipality has a special role, definitely. Now everyone is working with sustainability and the challenges we have in society. But a publicly funded actor...this should be its number one mission: democracy, sustainability, and resource efficiency." Another respondent (R2) added that "it is not the actor with the biggest wallet or most people behind it that wins; we also have to consider the democratic implications." This resonates with long-standing tenets of urban planning to ensure that urban development activities are beneficial to all residents (Montin \& Granberg, 2007; Pierre \& Sundström, 2009).

To guard public interests, the respondents emphasised that the municipality is responsible for ensuring that different interests are balanced and that collaborating companies are not given preferential treatment (Nalbandian, 1999). One smart city strategist (R11) argued:

We must guarantee that companies with whom we partner don't get priority to information, and favoured positions in building the smart city. We can- not only define the process of how to technically test something, but also how to do it in a legally responsible way.

Another respondent (R2) described a specific meeting with a technology company: "I met an entrepreneur who had done a super cool technical gadget that could monitor everything. But the problem is that they had not considered any regulations and issues of integrity at all." Thus, the municipality serves as the litmus test for public suitability and collective benefits of proposed experiments.

Relatedly, the local government is positioned to advocate for all citizens and to ensure similar input from and benefits to different citizen groups: "The municipality is particularly responsible for inviting citizens and their perspectives" (R10) and "must ensure that different solutions are suitable for all groups in society" (R7). An innovation strategist (R2) concluded that "there are lots of wonderful things out there, but if that doesn't mean increased quality of life for our citizens, then we shouldn't do it." This reflects the widespread understanding of the local government as the 'voice of the people' (e.g., Scharpf, 1999) and the guardian of democratic values.

The guarding function is complicated by the fact that local governments have vast and differentiated operations, with responsibilities for welfare as well as business development and the built environment. This can produce conflicts between municipal goals when working on experiments. As one respondent (R7) noted:

We must raise and discuss conflicting objectives. Some solutions work from one perspective but may not work for other reasons. We are constantly confronted with conflicting objectives; we need to see the city as a whole, and try to explain that to other actors.

Thus, being a guardian requires a comprehensive overview of the city (similar to the amplifying function), a commitment to resolving conflicts between multiple stakeholders (similar to the facilitating function), and the protection of the collective values of all citizens. Unlike the previous four strategic functions, the guarding is exclusive to municipalities and embodies the government's democratic commitment to their constituents.

\section{Conclusions}

The aim of this article was to examine the multiple strategic functions played by municipalities in experimental governance. We began by developing an analytic framework of strategic local government functions inspired by previous research on urban experiments but with a new focus on the broader processes of experimental governance. We then applied this framework to study contemporary experimental governance practices in Stockholm to understand how the municipality 
performs these functions in practice and, in turn, how this challenges the local government on multiple fronts (Berglund-Snodgrass \& Mukhtar-Landgren, 2020). These functions are not new to municipalities but the recent emphasis on urban experimentation reframes and combines them in important ways. This is particularly evident in the amplifying function and its emphasis on upscaling and replication. The respondents recognised the importance of these activities but also noted multiple challenges to capitalising on experimental results.

Meanwhile, traditional planning activities related to visioning, facilitating urban development processes, and guarding the public good are recognised as natural and self-evident to municipal officials, but are often underemphasised in the empirical findings on experimental governance. The visioning function is recognised as important but difficult to perform because it requires prioritisation among many municipal goals while guarding the public good is a function that is unique to public actors. In all of these functions, the respondents stressed the importance of having a broad overview of different departments within the municipal government to ensure that experiments benefit all citizens and to avoid disruptions and negative impacts to existing services. In addition, they recognised the enduring challenges of connecting up experimental governance activities with broader municipal aims and objectives.

The empirics in this study are limited to municipal representatives who are driving innovation activities. It would also be helpful to understand how other stakeholders both within and outside of the municipality interpret the work of the local government in experimental governance. Additionally, the study is based on one municipality and it would be useful to conduct further research to compare and contrast the findings in Stockholm with other cities to see how size, location, governance structures, and historical development patterns influence experimental governance processes. We would expect that the strategic functions of municipalities would have vary by context and might include additional functions that we have not identified here. Finally, all of the functions described in the article are portrayed as constructive and it would be useful to consider the ways that municipalities actively discourage experimental governance by regulating or obstructing. This might highlight some of the agonistic aspects of experimental governance and how the different functions contradict one another.

Overall, the insights on experimental governance in Stockholm reveal a multitude of overlapping and reinforcing functions for local governments that draw upon conventional modes of governance as well as emergent modes of experimental governance. Experimental governance is not replacing conventional governance per se but is instead extending and enhancing how urban planning draws upon discrete interventions to inform long-term policies and regulations (Karvonen, 2018). Through visioning, facilitating, supporting, ampli- fying, and guarding, municipalities are influencing the interventions of experimental stakeholders while also making subtle but important changes to the governance of cities and regions. These functions will have important and long-lasting implications on the urban planning practices of the twenty-first century.

\section{Acknowledgments}

Thank you to Hans Westlund, Kersti Karltorp, and Sara Brorström for their comments and suggestions.

\section{Conflict of Interests}

The authors declare no conflict of interests.

\section{References}

Agger, A., \& Sørensen, E. (2018). Managing collaborative innovation in public bureaucracies. Planning Theory, 17(1), 53-73.

Agranoff, R., \& McGuire, M. (2001). Big questions in public network management research. Journal of Public Administration Research and Theory, 11(3), 295-326.

Berglund-Snodgrass, L., \& Mukhtar-Landgren, D. (2020). Conceptualizing testbed planning: Urban planning in the intersection between experimental and public sector logics. Urban Planning, 5(1), 96-106.

Berkhout, F., Verbong, G., Wieczorek, A. J., Raven, R., Lebel, L., \& Bai, X. (2010). Sustainability experiments in Asia: Innovations shaping alternative development pathways? Environmental Science \& Policy, 13(4), 261-271.

Bos, J. J., \& Brown, R. R. (2012). Governance experimentation and factors of success in socio-technical transitions in the urban water sector. Technological Forecasting and Social Change, 79(7), 1340-1353.

Brorström, S. (2015). Implementing innovative ideas in a city: Good solutions on paper but not in practice? International Journal of Public Sector Management, 28(3), 166-180.

Bryson, J. M., Crosby, B. C., \& Bloomberg, L. (2014). Public value governance: Moving beyond traditional public administration and the new public management. Public Administration Review, 74(4), 445-456.

Bulkeley, H., \& Castán Broto, V. (2013). Government by experiment? Global cities and the governing of climate change. Transactions of the Institute of British Geographers, 38(3), 361-375.

Bulkeley, H., Coenen, L., Frantzeskaki, N., Hartmann, C., Kronsell, A., Mai, L., . . . Voytenko Palgan, Y. (2016). Urban living labs: Governing urban sustainability transitions. Current Opinion in Environmental Sustainability, 22, 13-17.

Bulkeley, H., \& Kern, K. (2006). Local government and the governing of climate change in Germany and the UK. Urban Studies, 43(12), 2237-2259.

Bulkeley, H., Marvin, S., Voytenko Palgan, Y., McCormick, 
K., Breitfuss-Loidl, M., Mai, L., . . . Frantzeskaki, N. (2019). Urban living laboratories: Conducting the experimental city? European Urban and Regional Studies, 26(4), 317-335.

City of Stockholm. (2015). Vision 2040: A Stockholm for everyone. Stockholm: City of Stockholm. Retrieved from https://international.stockholm.se/ globalassets/vision-2040_eng.pdf

City of Stockholm. (2018). Översiktsplan: Stockholm city plan. Stockholm: City of Stockholm. Retrieved from https://vaxer.stockholm/globalassets/tema/ oversiktplan-ny_light/english_stockholm_city_ plan.pdf

City of Stockholm. (2020a). Innovation. City of Stockholm. Retrieved from https://start.stockholm/omstockholms-stad/sa-arbetar-staden/innovation

City of Stockholm. (2020b). Norra Djurgårdsstaden [Royal seaport]. City of Stockholm. Retrieved from https:// vaxer.stockholm/omraden/norra-djurgardsstaden

City of Stockholm. (2020c). Så arbetar staden [How the city works]. City of Stockholm. Retrieved from https://start.stockholm/om-stockholms-stad/saarbetar-staden

City of Stockholm. (n.d.-a). Urban ICT Arena. City of Stockholm. Retrieved from https://smartstad.stockholm/ urban-ict-arena

City of Stockholm. (n.d.-b). Strategi för Stockholm som smart och uppkopplad stad: Bilaga 1: Strategi [Strategy for Stockholm as a smart and connected city: Appendix 1: Strategy]. Stockholm: City of Stockholm. Retrieved from https://smartstad.stockholm/wpcontent/uploads/sites/10/2019/09/Bilaga-1Strategi-for-en-smart-och-uppkopplad-stadStockholms-stad.pdf

de Jong, M., Joss, S., Schraven, D., Zhan, C., \& Weijnen, M. (2015). Sustainable-smart-resilient-low carboneco-knowledge cities: Making sense of a multitude of concepts promoting sustainable urbanization. Journal of Cleaner Production, 109(C), 25-38.

Evans, J., \& Karvonen, A. (2014). 'Give me a laboratory and I will lower your carbon footprint!': Urban laboratories and the governance of low-carbon futures. International Journal of Urban and Regional Research, 38(2), 413-430.

Evans, J., Karvonen, A., \& Raven, R. (2016). The experimental city. London: Routledge.

Flyvbjerg, B. (2006). Five misunderstandings about casestudy research. Qualitative Inquiry, 12(2), 219-245.

Frantzeskaki, N., Hölscher, K., Wittmayer, J. M., Avelino, F., \& Bach, M. (2018). Transition management in and for cities: Introducing a new governance approach to address urban challenges. In N. Frantzeskaki, K. Hölscher, M. Bach, \& F. Avelino (Eds.), Co-creating sustainable urban futures: A primer on applying transition management in cities (pp. 1-40). Cham: Springer.

Gaffikin, F., \& Sterrett, K. (2006). New visions for old cities: The role of visioning in planning. Planning The- ory \& Practice, 7(2), 159-178.

GrowSmarter. (n.d.). Lighthouse city: Stockholm. GrowSmarter. Retrieved from https://grow-smarter.eu/ lighthouse-cities/stockholm

Hodgson, D., Fred, M., Bailey, S., \& Hall, P. (Eds.). (2019). The projectification of the public sector. London: Routledge.

Hölscher, K., Avelino, F., \& Wittmayer, J. M. (2018). Empowering actors in transition management in and for cities. In N. Frantzeskaki, K. Hölscher, M. Bach, \& F. Avelino (Eds.), Co-creating sustainable urban futures: A primer on applying transition management in cities (pp. 131-158). Cham: Springer.

Iveroth, S. P., Vernay, A. L., Mulder, K. F., \& Brandt, N. (2013). Implications of systems integration at the urban level: The case of Hammarby Sjöstad, Stockholm. Journal of Cleaner Production, 48, 220-231.

Jessop, B. (1997). Capitalism and its future: Remarks on regulation, government and governance. Review of International Political Economy, 4(3), 561-581.

Karvonen, A. (2018). The city of permanent experiments? In B. Turnheim, P. Kivimaa, \& F. Berkhout (Eds.), Innovating climate governance: Moving beyond experiments (pp. 201-215). Cambridge: Cambridge University Press.

Karvonen, A., Evans, J., \& van Heur, B. (2014). The politics of urban experiments: Radical change or business as usual? In M. Hodson \& S. Marvin (Eds.), After sustainable cities? (pp. 116-127). London: Routledge.

Kern, K. (2019). Cities as leaders in EU multilevel climate governance: Embedded upscaling of local experiments in Europe. Environmental Politics, 28(1), 125-145.

Kickert, W. J. M., \& Koppenjan, J. F. M. (1997). Public management and network management: An overview. In W. J. M. Kickert, E. H. Klijn, \& J. F. Koppenjan (Eds.), Managing complex networks: Strategies for the public sector (pp. 35-61). London: Sage.

Kivimaa, P., Hildén, M., Huitema, D., Jordan, A., \& Newig, J. (2017). Experiments in climate governance: A systematic review of research on energy and built environment transitions. Journal of Cleaner Production, 169, 17-29.

Kronsell, A., \& Mukhtar-Landgren, D. (2018). Experimental governance: The role of municipalities in urban living labs. European Planning Studies, 26(5), 988-1007.

Kronsell, A., \& Mukhtar-Landgren, D. (2020). Experimental governance of smart mobility: Some normative implications. In A. Paulsson \& C. H. Sørensen (Eds.), Shaping smart mobility futures: Governance and policy instruments in times of sustainability transitions (pp. 119-135). Bingley: Emerald.

Laakso, S., Berg, A., \& Annala, M. (2017). Dynamics of experimental governance: A meta-study of functions and uses of climate governance experiments. Journal of Cleaner Production, 169, 8-16.

Lam, D. P. M., Martín-López, B., Wiek, A., Bennett, E. 
M., Frantzeskaki, N., Horcea-Milcu, A. I., \& Lang, D. J. (2020). Scaling the impact of sustainability initiatives: A typology of amplification processes. Urban Transformations, 2, 1-24.

Lundquist, L. (1998). Demokratins väktare: ämbetsmännen och vårt offentliga etos [The guardians of democracy: The officials and our public ethos]. Lund: Studentlitteratur.

March, J. G., \& Olsen, J. P. (1989). Rediscovering institutions: The organizational basis of politics. New York, NY: Free Press.

McFarlane, C. (2011). Learning the city: Knowledge and translocal assemblage. Oxford: Wiley-Blackwell.

Meadowcroft, J. (2009). What about the politics? Sustainable development, transition management, and long term energy transitions. Integrating Knowledge and Practice to Advance Human Dignity, 42(4), 323-340.

Mey, F., Diesendorf, M., \& MacGill, I. (2016). Can local government play a greater role for community renewable energy? A case study from Australia. Energy Research \& Social Science, 21, 33-43.

Montin, S., \& Granberg, M. (2007). Moderna kommuner [Modern municipalities]. Malmö: Liber.

Mukhtar-Landgren, D., \& Smith, G. (2019). Perceived action spaces for public actors in the development of mobility as a service. European Transport Research Review, 11(1), 32.

Mukhtar-Landgren, D., Kronsell, A., Voytenko Palgan, Y., \& von Wirth, T. (2019). Municipalities as enablers in urban experimentation. Journal of Environmental Policy \& Planning, 21(6), 718-733.

Nalbandian, J. (1999). Facilitating community, enabling democracy: New roles for local government managers. Public Administration Review, 59(3), 187-197.

Nyström, A-G., Leminen, S., Westerlund, M., \& Kortelainen, M. (2014). Actor roles and role patterns influencing innovation in living labs. Industrial Marketing Management, 43(3), 483-495.

Pierre, J. (2011). The politics of urban governance. Basingstoke: Palgrave.

Pierre, J., \& Sundström, G. (2009). Samhällsstyrning $i$ förändring [Societal governance in change]. Stockholm: Liber.

Raven, R., Sengers, F., Spaeth, P., Xie, L., Cheshmehzangi, A., \& de Jong, M. (2019). Urban experimentation and institutional arrangements. European Planning Studies, 27(2), 258-281.

Rutherford, J. (2008). Unbundling Stockholm: The net- works, planning and social welfare nexus beyond the unitary city. Geoforum, 39(6), 1871-1883.

Rutherford, J. (2020). Redeploying urban infrastructure: The politics of urban socio-technical futures. Cham: Palgrave Macmillan.

Scharpf, F. W. (1999). Governing in Europe: Effective and democratic? Oxford: Oxford University Press.

Scholl, C., \& Kemp, R. (2016). City labs as vehicles for innovation in urban planning processes. Urban Planning, 1(4), 89-102.

Sengers, F., Wieczorek, A. J., \& Raven, R. (2019). Experimenting for sustainability transitions: A systematic literature review. Technological Forecasting and Social Change, 145, 153-164.

Solesvik, M. Z. (2017). The Triple Helix model for regional development and innovation: Context of Nordic countries. Forum Scientiae Oeconomia , 5(4), 5-21.

Torfing, J. (2012). Samarbejdsdrevet innovation i den offentlige sektor: Drivkræfter, barrierer og behovet for innovationsledelse [Collaborative innovation in the public sector: Drivers, barriers and the need for innovation management]. Scandinavian Journal of Public Administration, 16(1), 27-47.

van der Heijden, J. (2015). The role of government in voluntary environmental programmes: A fuzzy set qualitative comparative analysis. Public Administration, 93(3), 576-592.

van der Heijden, J. (2018). City and subnational governance. In A. Jordan, D. Huitema, H. van Asselt, \& J. Forster (Eds.), Governing climate change: Polycentricity in action? (pp. 81-96). Cambridge: Cambridge University Press.

Vanolo, A. (2017). City branding: The ghostly politics of representation in globalising cities. London: Routledge.

Warbroek, W. D. B., \& Hoppe, T. (2017). Modes of governing and policy of local and regional governments supporting local low-carbon energy initiatives: Exploring the cases of the Dutch regions of Overijssel and Fryslân. Sustainability, 9(1), 1-36.

Wolfram, M., \& Frantzeskaki, N. (2016). Cities and systemic change for sustainability: Prevailing epistemologies and an emerging research agenda. Sustainability, 8(2), 144.

Wolfram, M., van der Heijden, J., Juhola, S., \& Patterson, J. (2019). Learning in urban climate governance: Concepts, key issues and challenges. Journal of Environmental Policy \& Planning, 21(1), 1-15.

\section{About the Authors}

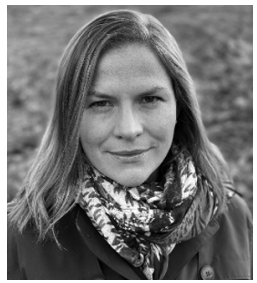

Erica Eneqvist is a PhD Candidate in the Department of Urban Planning and Environment at the KTH Royal Institute of Technology in Stockholm and a Project Manager at the Research Institutes of Sweden (RISE). She conducts research on municipalities and how they are influenced by experiments, partnerships, and other types of innovation work, with a particular focus on the public good. She is currently involved in projects related to the organisational capacity for innovation within municipalities. 
Andrew Karvonen is Associate Professor and Director of Doctoral Studies in the Department of Urban Planning and Environment at the KTH Royal Institute of Technology in Stockholm. He conducts research on the politics and practice of sustainable urban development with a particular focus on experiments, laboratories, and innovation. His most recent book, edited with Federico Cugurullo and Federico Caprotti, is Inside Smart Cities: Place, Politics and Urban Innovation (2019, Routledge). 